Boise State University

ScholarWorks

4-1-1991

From Claiming Credit to Avoiding Blame: The Evolution of Congressional Strategy for Asbestos Management

Charlotte Twight

Boise State University 


\title{
From Claiming Credit to Avoiding Blame: The Evolution of Congressional Strategy for Asbestos Management
}

\author{
CHARLOTTE TWIGHT*, Economics, Boise State University
}

\section{ABSTRACT}

This paper develops a theory synthesizing credit-claiming and blameavoidance explanations of congressional behavior and evaluates it against asbestos policy in the United States from the I920s through the I 980 s. Public policy is viewed as shaped by officeholders' ability to achieve political ends through augmenting information costs and other transaction costs facing the public. Public perceptions are seen both as the endogenous product of congressional information-cost manipulation and as an exogenous constraint that changes in identifiable ways over time. Different policy stances - open credit claiming, concealed credit claiming, early-stage blame avoidance, and full-scale blame avoidance are predicted to emerge in response to specified conditions, yielding implications about the expected timing of public policy changes. Specific types of transaction-cost manipulation are predicted to accompany the identified policy stances. The US asbestos policy experience is shown to be consistent with the predictions of the model.

\section{Introduction}

This article develops a theory synthesizing credit-claiming and blameavoidance explanations of legislators' behavior and evaluates it against asbestos policy in the United States from the I920s through the Ig8os. Whereas previous writers often have adopted 'dominant-strategy' explanations that identify either credit claiming or blame avoidance as the chief motive of political actors, this paper examines these strategies as alternative tools whose serviceability changes in predictable ways in response to changes in exogenous constraints. Central to the analysis is recognition of officeholders' changing ability over time to achieve political ends through augmenting information costs and other transaction

\footnotetext{
* The author thanks Robert Higgs and an anonymous reviewer for comments on an earlier draft of this article.
} 


\section{54 Charlotte Twight}

costs facing the public. Like the political leitmotifs of credit and blame, such transaction-cost augmentation is not confined to asbestos policymaking nor to the US Congress: it is a widespread, perhaps universal, characteristic of governments. Evidence regarding linkages between transaction-cost augmentation and political choices to claim credit or avoid blame therefore may prove useful to those analysing government policymaking in other nations and institutional contexts.

In the United States, despite knowledge of the dangers of asbestos dating from at least the mid-i93os, the government acted chiefly as a promoter of the industry well into the I970s. This article analyses the US government's policy transition from promoter to regulator of the asbestos industry, with particular attention to the timing of that transition. It explains how optimal political strategies on this issue have changed over time by analysing determinants of congressional choices between credit-claiming and blame-avoidance strategies. ${ }^{1}$ In so doing, the model describes public perceptions as both an endogenous product of politicians' information-cost manipulation and an exogenous constraint that changes in identifiable ways over time.

The analysis has important implications for public policy formulation both in the United States and in countries governed by different institutional structures. Most directly, political leaders in other nations and contexts may display credit-claiming and blame-avoidance patterns analogous to those observed here. Moreover, as noted above, mechanisms employed by politicians in this case - such as the transaction-cost augmenting devices described in section 3 - seem likely to characterize other nations' governmental institutions as well as other levels of government within the United States. It is clear, for example, that the US President and other heads of state routinely use transaction-cost augmentation in their efforts to claim credit and avoid blame (see Rose, I977: I I-I4). In more than one dimension, the asbestos problem appears representative of a broader class of policy issues that transcend narrowly national concerns.

Section 2 of this paper summarizes key elements of the pertinent literature. Section 3 presents an extension of the theory that more fully unifies and integrates 'credit-claiming' and 'blame-avoidance' analyses of legislators' behavior. In section 4 we examine the US government's asbestos policy from the i 920 s through the I 980 os against the theoretical framework presented in previous sections. Section 5 suggests avenues for future research, including potential international application of the model. 


\section{The Dominant-Strategy Literature and Beyond}

Reelection is assumed to be an overarching objective of politicians (Peltzman, I976; Fiorina, I977; Mayhew, I974; Weaver, I986). Even if a politician is motivated chiefly by desire to serve his concept of the public interest, reelection is prerequisite to those larger ends and so must serve as a proximate political objective. The real issue is what political strategies best serve this goal.

Well into the I980s policy scientists routinely averred that 'creditclaiming' was the lifeblood of congressmen seeking reelection, their dominant strategy. Given the information asymmetries characteristic of political decisionmaking, it was expected that members of Congress would fully exploit opportunities to claim credit for political benefits that flowed to constituents to the outer limits of the public's credulity. In situations where credit claiming for delivering benefits was not credible, Mayhew (1974: 52-56, 59-62) suggested that politicians gained analogous electoral rewards by 'position-taking', embracing politically advantageous policy postures and taking credit for the propriety of their views rather than for actually delivering the political goods.

Challenging the relative importance of credit-claiming political behavior, R. Kent Weaver ( 1986 ) proposed blame-avoidance as the dominant strategy of reelection-minded congressmen. While not asserting that politicians never use alternative strategies, Weaver ( I 986: 37 I, 372) stated unequivocally that 'Politicians are motivated primarily by the desire to avoid blame for unpopular actions rather than by seeking to claim credit for popular ones. ... [M] ost officeholders seek above all not to maximize the credit they receive but to minimize blame.' Driving this conclusion was the observation that voters display a 'negativity bias': they are more likely to notice (and to cast a vote based upon) negative personal experiences for which they blame politicians than positive ones for which they credit politicians. Hence, in Weaver's analysis, successful politicians must discount electoral benefits that flow from credit-claiming strategies and remain differentially sensitive to political actions capable of generating blame.

Weaver (I986: 379) envisioned the choice between credit-claiming and blame-avoidance strategies as critically dependent on the 'perceived net benefits' and 'perceived net costs' to a policymaker's constituencies, referring chiefly to the politician's perceptions of the net costs and benefits to his constituents. When a politician judged a policy to entail high net costs for one segment of his constituency but high net benefits for another constituent group, blame avoidance was predicted to be the dominant strategy. Weaver (I988: 22-25) later described the choice between credit claiming and blame avoidance as a function of a pro- 


\section{I $5^{6} \quad$ Charlotte Twight}

posal's effects on the policymaker's own policy or personal interests as well as its perceived net effects on constituents. In his full enumeration of the determinants of blame-avoidance behavior, Weaver (r986: 378) identified risk aversion, reelection desires, the number of parties or candidates, the distribution of constituency costs and benefits, and 'how constituency costs and benefits are translated into political gains and losses'.

But the ease or difficulty of translating constituency costs and benefits into political losses and gains is not entirely exogenously determined. That is the core issue of this paper. Given a politician's perceptions of likely constituent impacts, constituents' perceptions of and responsiveness to those benefits and costs can be manipulated within certain bounds when so doing serves the politician's electoral or ideological objectives. Even the size of constituent groups is to some extent endogenous, for transaction-cost augmentation (described in the following section) allows a losing group to be kept 'small' in political effectiveness through lack of information or other impediments to collective action. Weaver ( 1986 : $384-386$; r988: $25^{-29}$ ) treated these issues tangentially, noting the ability of politicians to limit the agenda, redefine issues, and manipulate perceptions in self-serving ways.

This paper investigates in more detail the determinants of such behavior. As we will see in the next section, the feasible bounds of this manipulation change over time due to exogenous changes in political constraints, and the shifting bounds of feasible transaction-cost manipulation provide a key determinant of politicians' policy choices.

\section{Manipulation of Transaction Costs. Or, How to Eat Your Cake and Have It Too (At Least Temporarily)}

Information asymmetries are fundamental to politics. Although the existence of information asymmetries has been recognized for decades, only recently has research in the policy sciences begun to focus more fully on the ability of politicians and bureaucrats to exploit such asymmetries to serve their own ends. Recent studies - whether examining legislators' incentives to conceal private information strategically (Austen-Smith \& Riker, 1987, 1990), bureaucrats' and legislators' mutual incentives to manipulate information given reciprocal informational uncertainties (Bendor et al., 1987), government officials' incentives to conceal costs from the public (Higgs, I987) and use other strategies to enhance their autonomy (Nordlinger, I98I), or officeholders' broader incentives to manipulate a wide range of politically relevant transaction costs (Crew \& Twight, I990; Twight, I988) - document on various levels the ability of politicians and bureaucrats to 
manipulate in self-serving ways transaction costs ${ }^{2}$ facing each other and the public.

What has not been done is to tie the new literature on governmental transaction-cost augmentation to existing insights into the politics of credit claiming and blame avoidance. As shown below, the synthesis of these approaches helps to explain the time path of politicians' policy choices.

Transaction-cost augmentation denotes efforts by government officeholders to increase politically relevant information costs as well as other costs (e.g., organizational costs) of collective political action (Twight, 1988). The target may be voters (as in the interaction between members of Congress and the public) or it may be particular groups within government (as in the interaction between an agency and a congressional oversight committee, or between committee members and Congress at large). Given the unavoidable existence of positive transaction costs in political settings, officeholders can and do augment those 'natural' transaction costs to expand their autonomy and thereby serve their own political ends.

Congressional examples of transaction-cost augmentation include euphemistic naming of statutes, concentrating the benefits and diffusing the harm associated with governmental actions, misrepresenting the anticipated consequences of legislation, concealing the costs of governmental actions, attaching parochial riders to politically safe bills, and the like. ${ }^{3}$ The common thread in these seemingly disparate examples is that each either raises information costs facing the public or raises other costs of collective action. If statutes are misleadingly named, if harmful consequences are distributed widely so as to reduce per capita costs and thereby dilute incentives for political resistance, if expected effects of legislation are misrepresented, if governmental costs are concealed, or if parochial riders are buried in politically safe bills - then the (transaction) cost to the public of perceiving and reacting politically to governmental actions increases. Congressional autonomy is thereby expanded.

Extending earlier work on 'fiscal illusion' (Buchanan, 1967; West \& Winer, I980), recent studies have identified determinants of transactioncost augmentation and its implications for the efficiency characteristics of legislation (Twight, I988; Crew \& Twight, 1990). An officeholder's decision favoring a transaction-cost-increasing measure, ceteris paribus, is expected to be a positive function of: the complexity of the issue, the existence of an appealing justification for the measure [Lindsay's ( 1976 ) 'fog factor'], the existence and magnitude of third-party payoffs, executive support and party support for the measure, expected positive impacts of the measure on the job security and perquisites of the legislator, and the perceived importance of the measure to constituents, inter 


\section{I $5^{8} \quad$ Charlotte Twight}

alia. Such a decision is expected to be a negative function of media attention or other publicity highlighting the measure's transaction-costincreasing features. While ideology plays a more complex role, the model generates predictions about what types of transaction-cost-augmenting measures will be favored by those holding different ideological views (Twight, I988: I34-1 35). The passage of time plays a less determinate role in the model, since time may both mitigate complexity and facilitate entrenchment of interest groups.

I will argue in the following pages that transaction-cost augmentation plays a dual yet complementary role with respect to a politician's choice between blame avoidance and credit claiming. On the one hand, the feasible bounds of transaction-cost augmentation determine which of these strategies will predominate regarding a particular policy issue at a given point in time. Once that strategy emerges, however, transactioncost augmentation then will be used in its service: that is, the specific types of transaction-cost augmentation employed will be determined by the credit-claiming or blame-avoiding objectives of legislators.

This intertwining of choice of optimal policy strategy and transactioncost augmentation is complex. The decisions involved are those of individual legislators, and they will vary depending upon individual objectives and constraints. Nonetheless, the common electoral objective coupled with officeholders' assumed responsiveness to marginal political costs and benefits enables us to predict changes in aggregate outcomes. In fact, there are at least four possible scenarios, simultaneously driven (at the macro level) by the feasibility of transaction-cost manipulation and determining (at the micro level) the observed types of transactioncost manipulation strategies.

In what follows, I will use the example of public policies pertaining to long-latency disease-generating agents, since that is the focus of subsequent sections. However, the paradigm discussed below also may explain a wide variety of other public policies.

\section{I Open Credit Claiming}

Open credit claiming is the strategy of choice not only when, objectively, the associated benefits of a policy choice to a politician's constituents outweigh the aggregate costs (Weaver, I986: 379 ), but more generally when the political potency of the losers is smaller than that of the winners, even if the aggregate losses to losers outweigh aggregate gains to winners. Gains and losses, of course, must be (respectively) discounted and compounded to take into account the 'negativity bias' of voters. Nonetheless, in broad terms, high per capita gains to winners may inspire political activism capable of dominating low per capita but larger 
aggregate losses to losers, enabling politicians to claim credit for policy choices benefiting special interests without fear of reprisal from those harmed.

Essential to this outcome are per capita losses to losers that are - or can be made to appear - small. While substantial information asymmetries often characterize these situations, even with perfect information those experiencing small per capita losses often lack incentives to become politically active (e.g., consumers hurt by barriers to international trade). Without the ability to make potential per capita losses appear large, political entrepreneurs who might benefit from activating losers may be stymied by the losing constituency's lack of motivation. This political result thus does not depend on conspiracy among incumbents to benefit special interests. Political entrepreneurs or opposition parties simply will find it difficult to generate blame effectively unless expected or actual losses, per capita, become large enough to engage voters' political attention.

As the preceding example suggests, open credit claiming regarding a policy that creates numerous losers usually involves high natural transaction costs: ${ }^{4}$ that is, even if everyone attempted to minimize detrimental effects of transaction costs surrounding that policy issue, those costs would be large. High natural transaction costs might stem from the inherent complexity of an issue, low issue salience to constituents and the press, a naturally occurring concentration of benefits and dispersion of harm, or other circumstances.

But high natural transaction costs also facilitate transaction-cost augmentation, as the model's previously discussed determinants make clear. In these situations, congressional transaction-cost manipulation may involve spreading losses more widely than natural transaction costs dictate and fostering misinformation about the existence and nature of those losses. Such transaction-cost manipulation enables politicians to be open in their credit-claiming behavior, for those harmed in this case often fail to perceive either the nature or extent of the costs associated with the legislator's policy choice - and, even if they do, lack incentive to take political action.

\subsection{Concealed Credit Claiming}

As the availability of information about a public policy's adverse consequences grows, the feasibility and appeal of open credit claiming on behalf of the policy's beneficiaries diminishes. Provided that the nature of the harm is not yet common knowledge, however, there is still room (and incentive) for legislative action that benefits special interests while concealing from the general public the true extent of the policy's costs. 
Increased autonomy - to advance political or ideological objectives again is the postulated congressional motive.

At this stage, although natural transaction costs are falling, the balance has not tipped sufficiently to sustain entrepreneurial politics on behalf of the losers. Much of the increased information is likely to be in the hands of elites (policy specialists) within Congress, the executive branch, and elsewhere, groups whose economic and political interests often are aligned with the policy's traditional subgovernment relationships. These policy specialists often have much at stake economically and politically based on past actions (or expected future benefits) pertaining to the issue. To other groups, the policy issue at this stage is likely to remain obscure.

In these circumstances, the incentive grows for the congressional policy elite and other large stakeholders to manipulate transaction costs so as to conceal the harm and blunt Congress's and the public's responsiveness to it. This model of political behavior predicts more serious and aggressive efforts at cost concealment by these subgroups in such cases. For a time their efforts are likely to be successful, since information asymmetries and transaction-cost augmentation characterize intragovernmental relations as well as those between Congress and the public (Twight, I983: I09-I I 4; I988: I 46-148).

Credit claiming thus will survive during this period, but that credit claiming will be subdued, targeted more specifically to special-interest audiences, and rendered more difficult for the general public to perceive. Of the four situations described in this section, this case is most conducive to transaction-cost augmentation aimed at those harmed by congressional policy choices.

\subsection{Early-Stage Blame Avoidance}

Blame-avoiding behavior is predicted to begin when the feasible bounds of transaction-cost manipulation contract so as to make it impossible to deceive the general public about adverse consequences of a policy choice. Entrepreneurial politics on the issue becomes viable. In this situation, Congress will begin to take a variety of blame-avoiding actions with respect to those potentially harmed by a policy choice, including appointment of study commissions, delegation of responsibility to administrative agencies, and other blame-mitigating strategies identified by Weaver ( 1986 ). ${ }^{5}$ However, this is an intermediate stage short of fullscale blame avoidance. Consequently, legislators may continue to use transaction-cost augmentation to shield former policy beneficiaries from adverse public reaction.

In this case, the strategy likely to emerge is preliminary blame 
avoidance coupled with inconspicuous efforts to protect former beneficiary groups. For example, in the case of long-latency hazards whose dangers become widely known among the general public, Congress might support regulations that appear to be more stringent than they actually are - for instance, regulations whose loopholes require some scientific expertise to detect. Congress in this case mutes public reaction through blame avoidance buttressed by transaction-cost augmentation, sustaining for special interests greater political protection than a fully informed public would likely support.

Again, one expects greater knowledge, activism, and transaction-cost augmentation by congressional policy elites than by other members of Congress. Like the general public, nonspecialist members of Congress may be targets of misinformation by specialists, remaining uninformed about relevant legislative or regulatory loopholes.

\subsection{Full-Scale Blame Avoidance}

Full-scale blame avoidance becomes the strategy of choice when the potential costs to the public of a policy decision are severe, and exogenously determined public knowledge of these costs is substantial and - from the politician's perspective - unavoidable. Here, concealing the costs is not a viable political option. In this situation it is no longer politically rewarding to claim credit on behalf of those who would benefit from a policy entailing these costs. Instead, political rewards flow from avoiding the blame cast by potential victims.

In such circumstances politicians have incentives to disclaim prior knowledge, blaming others for not acting decisively or not calling the situation to their attention. They may manipulate information so as to exaggerate the threat to the potential victims. The bigger the perceived threat the greater the credit politicians can claim for avoiding harm to potential victims - a coalescing of blame-avoidance and credit-claiming strategies discussed below. One implication is that overregulation, when it occurs, is most likely to occur in what I have labeled as a full-scale blame avoidance situation. By exaggerating the problem and encouraging a 'crisis' mentality, politicians may engender support for a greater governmental role in dealing with the supposed crisis (Higgs, I987: 6267 ), thereby generating the greater electoral benefits associated with solving a problem of crisis proportions. The full range of blameavoidance strategies should be observed in this situation, with transaction-cost augmentation employed in service of the blame-mitigating objective.

Nonetheless, as Weaver (ig86: 395-396, note 6) recognized, blame and credit are not as distinct as the nomenclature suggests. For example, 
holding constant the way the policy choice is framed, another way of looking at the shift to full-scale blame avoidance is to conceptualize it as credit claiming with regard to potential victims (rather than beneficiaries) of the policy choice. [In the asbestos policy case examined below, this shift would entail avoiding being blamed by potential victims of asbestos-related disease - or, alternatively, claiming credit for policy choices that curtail harm to this group.] That is, the 'credit' involved is credit for avoiding blameworthy actions. Regardless of how the change is labeled, however, it entails a distinct shift in political attention from one set of constituent interests to another. The key to our analysis is what drives this change in officeholders' focus.

Gredit-claiming and blame-avoidance motivations typically coincide when officeholders in this situation find it advantageous to protect a policy's potential victims. When exogenous changes in political constraints dictate that officeholders alter their policies so as to avoid the blame of interests previously harmed, they will attempt to claim credit for protecting these interests while seeking to avoid blame for harm that (intentionally or unintentionally) slips - and has slipped - through the cracks. Beyond conceptualising credit claiming and blame avoidance as different 'lenses' for viewing the same behavior, therefore, we expect a symbiosis in such cases between officeholders' credit-claiming and blame-avoidance strategies with respect to a single interest group.

\section{US Asbestos Policy: Credit and Blame}

Asbestos - a carcinogen known to cause asbestosis (a progressive fibrosis of the lungs), lung cancer, mesothelioma (an extremely painful and always fatal cancer of the lining of the chest or stomach), and other cancers - has been called the 'pollutant of the century' (US House, ig86a: 53). A general term denoting a group of fibrous minerals, asbestos long has been prized for its flexibility and its ability to withstand fire and chemicals. US congressional policy regarding asbestos provides evidence on the linkage between transaction-cost parameters confronting politicians, their choice of credit-claiming or blame-avoiding strategies, and their use of transaction-cost augmentation in service of the chosen strategies.

Congressional policies with respect to asbestos have run the gamut from open credit claiming to full-scale blame avoidance. As shown below, the timing of these policy changes appears consistent with the model presented in Section 3 while inconsistent with dominant-strategy models. Despite some overlap in the transition years, US asbestos policy has evolved as this model predicts in conjunction with identifiable changes in external constraints on transaction-cost augmentation. 


\section{I Credit Claiming Before 1945}

Until the mid-r 930 , federal asbestos policy was formulated in the absence of widespread understanding, by the public or by Congress, of the mineral's dangers. Despite the fact that, between I9I3 and I9I9, six states made asbestosis a compensable occupational disease - and despite the US Department of Labor's I 918 report that insurance companies were refusing to insure asbestos workers because of their 'assumed health risks' - that knowledge had not been assimilated by most policymakers (Maguire, 1983: 597; US House, 1981: 34; Hoffman, I918).

In this context, Congress took asbestos-related actions allowing members to claim credit with affected interest groups. The credit-claiming environment resembled that for domestic producers of nontoxic products - shoes, sugar, tin - in that affected politicians could engineer political approval of parochial measures without need to conceal service activities benefiting these constituencies.

Since the US has never been a major producer of raw asbestos fiber, congressional policy most often benefited domestic producers of manufactured asbestos products. For example, in its tariff policies from the late i 800 s to the I920s, Congress established io per cent to 40 per cent tariffs on imported asbestos products, permitting the domestic industry to grow 'from a capitalization of a few hundred thousand dollars, and employing not over Ioo men, to the industry of to-day [1 $192 \mathrm{I}]$ with a capital and surplus of between fifty and seventy-five million and employing about 20,000 men....' (US House, I92 I: 34 I 2). Protectionist measures were put forth routinely with industry advocates extolling the mineral's virtues while passing samples of raw and manufactured asbestos products around the room for congressmen to admire (US House, I929: 7146; US House, I92 I: 341 I).

Although parochial motivations at that time did not require concealment, transaction-cost augmentation was evident. Tariffs were put forth in the name of fairness and competition to 'equalize production cost' between US firms and foreign competitors. And when, under the National Recovery Administration, the asbestos products industry was given cartel-like powers in r 933, the new arrangement was called a 'code of fair competition'.

\subsection{Credit Claiming, 1945-1969}

Understanding when government officials knew of asbestos-related health threats is crucial to the interpretation of asbestos policy after World War II. Elsewhere, I have documented early knowledge of the dangers of asbestos by many within government (Twight, 1991). In 
what follows, we trace the widening sphere of such governmental understanding, with particular attention to congressional stockpiling policy, the Bureau of Mines, and the Navy.

We will see that much of the information that might have inspired remedial congressional action on the asbestos issue during this period was concentrated in bureaucracies whose missions, cultures, and constraints discouraged aggressive action on this issue. Within the Navy, an aggressive stance regarding the negative health effects of asbestos would have seemed incompatible with the Navy's defense mission (especially during World War II); within the Bureau of Mines, such a stance would have seemed incompatible with that Bureau's commitment to mining interests. Congressional oversight in these areas, often aligned with the same interests, faced similar incentives. Those within Congress most likely to encounter the new information often had incentives to block its dissemination.

To the average member of Congress, the asbestos issue thus remained obscure. Given its complexity and lack of publicity, the issue gained little salience with either Congress at large or the public: hence, despite the new knowledge, no effective demand was placed on Congress for asbestos regulation. Existing institutional structures tended to compartmentalize emerging knowledge about asbestos hazards in agencies and committees with little incentive to pursue the issue.

However, by the mid-i93os, an important subset of government officeholders was aware of the by then 'widely accepted' scientific fact that inhalation of asbestos dust 'could cause asbestosis, often fatal' (US House, r 982a: 58). There is contemporaneous evidence that some members of Congress were apprised of these dangers. For example, in i 936 hearings on silicosis and metal-mining conditions, senators were given a list describing occupational disease coverage in various states. The entry for North Carolina reported that 'Asbestosis and silicosis [are] included among the compensable diseases.' Asbestos and silica were described as 'the two principal dusty industries'. The text of the North Carolina provisions explicitly referred to 'disablement or death' resulting from asbestosis, silicosis, or lead poisoning (US Senate, I936: I9, 24-25). Nonetheless, the Committee on Education and Labor continued to focus primarily on silicosis, whose victims often died within a few months on the job. The long latency of asbestos-related disease veiled the drama instrumental in triggering congressional policy response (see Bosso, I 987: I I 5-I 25).

The US Public Health Service (PHS) also had early knowledge. In I 935 and 1938 PHS published reports documenting the prevalence of asbestosis in asbestos workers (Lanza, I935; Dreessen et al., I938). Dr. 
Edward Brandt of the US Department of Health and Human Services testified:

PHS began research into the health effects of asbestos exposure in the midI930's. These early research efforts found excessive lung disease (asbestosis) in asbestos workers and later suggested that lung cancer may occur more frequently in asbestos workers than in the general populations. In I938, based upon the limited data then available, PHS recommended tentative threshold limit value guidelines for controlling occupational exposure to asbestos until better data became available. ... (US House, i 983 b: 144 ).

Thus by the early ig40s the dangers of asbestos were known by a significant and expanding subset of political actors in the federal government. How did policy change to reflect this growing awareness? Public interest theories of regulation (Kelman, I987) would predict emergence of regulatory policies to protect the public from the known hazards. Weaver's ( I986) model likewise would suggest a policy change to blameavoidance mode. That did not happen. In fact, no major changes in asbestos regulation occurred until the ig7os - some thirty years later.

The only significant change that occurred during this period is that credit-claiming opportunities with respect to asbestos interests were restructured in ways making them less apparent to the public. ${ }^{6}$ Federal policy continued to protect asbestos industry interests, enabling affected officeholders to claim credit with those groups. But credit-claiming opportunities were cultivated in ways unlikely to receive widespread public scrutiny. As shown below, transaction-cost augmentation was used both to misinform the public about the dangers of asbestos and to deflect adverse political reaction to pro-industry policies.

Stockpile policy typified Congress's posture during this period. With the war emergency past, asbestos stockpile policy became the province of special interests, administered without regard to its health consequences for the general public. After the war, through sales authorized by Congress, the government sold the bulk of the asbestos stockpile into the private market, attaching no warning or labeling requirement regarding the product's proper use (US Bureau of Mines, r 946: 144). The government then undertook to stimulate and subsidize raw asbestos production in the United States. Using the Defense Production Act, the Domestic Minerals Program Extension Act of 1953, and other laws, the government subsidized exploration for and production of asbestos, purchasing much of the new output for the stockpile even though it was acknowledged to be below stockpile quality. As late as r 963 the US Office of Minerals Exploration financed up to 50 per cent of approved costs for asbestos exploration (US Bureau of Mines, I963: 25I).

Insiders acknowledged that there was no 'national defense' rationale 
for these actions, stating that 'all defense needs have been met' and that the purpose of the program was to 'assist the industry' (US House, i956: I8). Moreover, despite new evidence of the mineral's dangers, ${ }^{7}$ between I 967 and 1977 Congress approved issuance of ' 200 contracts for the sale of asbestos from the stockpile,' benefiting asbestos product manufacturers (for whom raw asbestos was an input) by authorising the release of 75,866 short tons of stockpiled asbestos into the stream of commerce (US House, I982b: 9; US House, r985a: 337-338). Nonetheless, the obscurity of stockpile policy and its politically cultivated cloak of national security kept these facts from the purview of most US citizens.

Other governmental strategies during this period overtly increased asbestos-related information costs facing the general public. For example, throughout the critical years, the US Bureau of Mines (BuMines) used its Minerals Yearbook to promote the asbestos industry, first concealing and later downplaying the mineral's dangers to human life. It is certain that BuMines knew of the dangers, for BuMines reported to the Eagle-Picher Company in I 932 that "It is now known that asbestos dust is one of the most dangerous dusts to which man is exposed", (quoted in Castleman, I986: 488). Yet between I935 and 1963, the BuMines yearbook's annual summary of literature relevant to the industry did not mention even one article documenting health hazards attributable to asbestos. Indeed, the word 'asbestosis' does not appear in the yearbook until I964. In the late ig6os BuMines ( 1967 : 208) described impending investigations as designed to discover 'if there are dangers' associated with asbestos. The yearbook lauded new asbestos products and uses throughout this period. In the I97os BuMines (I976: I 86) was still referring to the 'alleged health effects' of asbestos.

Similarly, the Navy's shipyard asbestos policies during this period served industry and the military bureaucracy to the detriment of shipyard asbestos workers and their families. Approximately 4.5 million workers were exposed to asbestos without warning of the hazard while working at government and contract shipyards during World War II. That the Navy knew of the hazard was indicated in a I 94 I memo from C. S. Stephenson, commander in charge of the Navy's Division of Preventive Medicine, stating that "we are having a considerable amount of work done in asbestos and from my observations I am certain we are not protecting the men as we should. This is a matter of official report from several of our Navy yards"' (quoted in US House, I985a: I86).

Although the Navy in I943 adopted the PHS standard for asbestos exposure, most shipyards did not meet the safety requirements, and the Navy did not enforce the standard (US House, I980a: 673-674). During the war that decision was understandable, consistent with imperatives of 
mission and culture in the Navy. However, well into the I97os, the Navy withheld information from shipyard workers exposed to asbestos (US House, I985a: 186,305$)$. Although it carried out pulmonary function tests on some shipyard workers in the ig6os, it did not inform them of the medical results, even when the exams disclosed abnormalities consistent with asbestos-related disease in a majority of the workers X-rayed (US House, 1978: 268-271). Information about the asbestos hazard was not widely disclosed to shipyard workers until 1973, when the Navy first required caution signs and warnings regarding asbestos (US House, I983b: 205).

That both the Navy and BuMines took actions consistent with their respective missions and avoided raising bureaucratically relevant costs is not surprising. That Congress did not intercede also is not surprising, in light of the theory discussed in section 3. Congressional committees with oversight responsibilities were predominantly committed to the traditional missions of those bureaucracies. To the extent that they acquired knowledge, those committees had little incentive to publicize information about asbestos health risks that would interfere with traditional functions - for example, by raising the costs of achieving mission objectives. Dissemination of the knowledge thus was curtailed.

To the average member of Congress - and to the broader public asbestos health issues remained relatively obscure during the $1945^{-1} 9^{69}$ period. Institutional structures compartmentalized knowledge in ways that permitted policy specialists to play traditional subgovernment politics long after a transaction-cost-minimising model of government would have predicted a major policy change. Officeholders did not switch to a blame-avoidance strategy to protect user interests as soon as other theories would have predicted. Through congressional stockpiling policy, Bureau of Mines industry propaganda, and Navy information manipulation, political actors continued to pursue policies for which they could (privately) claim credit with asbestos producer interests. The costs to more diffuse groups were obscured, their political action blunted.

\subsection{Blame Avoidance, 1970-1985}

About 1970 Congress made the transition in its asbestos policy into what I have called 'early stage' blame avoidance. Why 1970? Around this time it became impossible to conceal from the general public - or nonspecialists in Congress - the hazards associated with asbestos use. The New York Academy of Sciences had held its historic international meeting on the biological effects of asbestos in 1964, calling worldwide attention to the asbestosis and fatal cancers that threatened not only 
those who worked with raw asbestos fibers but also those who worked with asbestos insulation (Selikoff et al., I965). The media and the courts began to open previously constricted conduits of information.

By 1970 twenty five years had elapsed since the massive asbestos exposures at the shipyards during World War II - enough time for the 20-40 year latency period to have expired for many affected workers. Asbestos-related lawsuits were becoming more common, creating graphic images of the human losses involved. Media attention increased accordingly. And the law itself was changing in ways that focused public attention on culpability: in 1973 the landmark Borel v. Fiberboard Paper Products et al. case greatly increased the liability of asbestos insulation manufacturers, easing plaintiffs' access to judicial remedies [493 Fed. $2 d$ I 076 (5th Cir., I 973)]. A Gallup poll taken in 1978 indicated that ' 50 per cent of all Americans knew asbestos exposure had an adverse effect on health' (US House, I98ob: 34I ).

From a theoretical perspective, these developments signaled a major change in exogenously determined constraints on politicians' ability to use transaction-cost augmentation in support of policies enabling them to claim credit with asbestos producer groups. A much larger fraction of the general public and of Congress knew that asbestos was dangerous, and it was apparent that - quite outside the control of politicians - such understanding would grow, not diminish. Since it was no longer possible to use transaction-cost augmentation to prevent this widespread understanding of the dangers, a rational politician now would find himself better served by active policy measures to counteract blame for asbestosrelated harm. In light of the serviceability of established political relationships, however, we would expect some backsliding by policy specialists benefiting asbestos producer interests. Thus we expect the use of transaction-cost augmenting strategies by policy experts to protect producer interests within the broader movement to establish for Congress a credible facade of blame avoidance.

Consistent with the blame-avoidance model, in the r97os and early i 980 C Congress passed numerous laws empowering federal agencies to deal with environmental hazards such as asbestos, as entrepreneurial politics on these issues drove the policy process. Among them were the Occupational Safety and Health Act ( 1970), Clean Air Act amendments (1970), the Consumer Product Safety Act ( 1972), the Toxic Substances Control Act ( 1976 ), and asbestos-in-schools laws described below. Here, we narrow our focus to asbestos-related uses of these broader powers. We will examine the congressional-bureaucratic policy nexus in asbestos regulations issued during this period by the Occupational Safety and Health Administration, the Consumer Product Safety Commission, and the Environmental Protection Agency. 
Because agency decisionmaking is the product of many influences not only Congress, but also the President, executives within the agency, agency staff, judicial rulings, and so forth - it is not accurate to conceptualize the near-term regulatory process as necessarily dominated by congressional desires. ${ }^{8}$ Indeed, we will see evidence below of the sometimes powerful influence of executive branch pressure on agency regulatory decisionmaking.

However, in the long run, one cannot disregard congressional acquiescence in agency regulatory activity. If a majority disagrees with agency action, Congress can express its desire to alter that policy by remedial exercise of its power to authorize and appropriate, to control agency mission and resources. In asbestos policymaking (particularly the school asbestos regulations discussed below), Congress sometimes has done so. The effectiveness of those control mechanisms is a separate issue, one dependent on the severity of principal-agent problems between Congress and the agency in a specific context. That issue aside, unless the agencies or relevant oversight committees have successfully deceived Congress, longer elapsed time without congressional countermove thus renders more plausible the characterization of agency policy as a manifestation of Congress's (constrained) will.

The general pattern documented below is that of Congress in early blame-avoidance mode - delegating responsibility, requiring studies, fracturing responsibility among competing agencies, passing the buck, using the agencies as scapegoats - while often not countermanding regulatory decisions that shielded producer interests.

\subsection{Occupational Safety and Health Administration (OSHA)}

There is much more to the OSHA story than blame avoidance - institutional impediments embedded in administrative structure (Shapiro \& McGarity, I989), the bureaucratic appeal of regulating visible safety hazards rather than chronic health hazards (Viscusi, I983; Wilson, I989), executive influence (Shapiro \& McGarity, I989; Kelman, I980), conflicting interest-group pressures stemming from the concentration of regulatory benefits and costs (Wilson, I 989), pro-protection values of agency officials (Kelman, I980), and the like. As Wilson ( I989: 247) notes, it is a story of congressional influence, not dominance. But it is the blame-avoiding function of OSHA's regulations for Congress that concerns us here.

OSHA asbestos regulations in many ways provide a model of early blame-avoidance strategy. How can one blame an agency or a Congress that oversees implementation of workplace asbestos standards increasing in stringency from a permissible exposure limit of I 2 fibers per cubic 


\section{I $70 \quad$ Charlotte Twight}

centimeter (f/cc) in I97 I to a time-weighted average of $5 \mathrm{f} / \mathrm{cc}$ in I972, $2 \mathrm{f} / \mathrm{cc}$ in 1976 , and $0.2 \mathrm{f} / \mathrm{cc}$ in 1986 ? $^{9}$

But appearances are misleading. By expressing the standard in fibers per cubic centimeter, OSHA made the rules seem more restrictive than they were. Since an average worker inhales 6 to ro million cubic centimeters of air on an 8-hour shift, the 1972 standard translated into $30,000,000$ to $50,000,000$ permissible fibers per shift, the 1976 standard I 2,000,000 to $20,000,000$ permissible fibers. A 'fiber' was defined to exclude asbestos fibers 5 microns in length or shorter, so that unlimited exposure to shorter fibers was allowed over and above the permissible exposure limit for the longer fibers. Although apparently less toxic than the longer fibers (Mossman et al., 1990), the shorter fibers were known to be capable of generating disease. Moreover, until i 986 the regulations only attempted to protect workers from asbestosis, not from cancers triggered by much lower exposure levels.

In addition, OSHA regulations throughout this period specified a type of optical microscopy called phase contrast microscopy (PGM) as the accepted method for measuring ambient asbestos levels. Although cheaper than the alternative transmission electron microscopy (TEM) techniques, PCM is less reliable, prompting asbestos expert Anthony Natale to label use of optical microscopy as 'this little-understood scandal' (US House, I986a: 300). While acknowledging PGM's deficiencies, OSHA justified its decision based on its lower costs (5 I Federal Register 22685, 20 June I 986).

Of course, there are legitimate arguments over the cost effectiveness, in a cost-benefit sense, of the alternative measurement techniques. In the circumstances, however, OSHA's asbestos regulations provided the best of both worlds for Congress. Delegation of responsibility - when coupled with apparently stringent regulations whose loopholes required technical knowledge to understand - virtually guaranteed that a congressman could avoid blame. Contrived increases in information costs reduced the risk that many would perceive the loopholes except those who benefited from them. And if they did, Congress had the agency as its scapegoat. It therefore makes political sense from a blame-avoidance perspective as well as an interest-group perspective that Congress over the years had 'harassed OSHA without fundamentally changing it' (Wilson, r989: 249).

\subsubsection{Consumer Product Safety Commission (CPSC)}

When Congress delegated authority to the CPSC in 1972 to issue regulations to control hazards in consumer products, it put another blameavoidance mechanism in place. Any future problems with consumer 
products could be - and, in the case of asbestos, were - blamed on the agency.

The CPSC issued no regulations governing asbestos-containing consumer products until 1977 , and Congress did not intervene. Household appliances and floor coverings, do-it-yourself household repair products, and even children's playthings (such as papier-mache containing up to $5^{\circ}$ per cent asbestos) were sold throughout this period without labeling their asbestos content. In I977, the CPSC banned two asbestos-containing products particularly dangerous to homeowners: drywall patching compounds and asbestos-containing emberising agents used in fireplaces. Labeling requirements were not established until ig86 (5 I Federal Register 33910, 24 September 1986).

An incident particularly revealing of the prevailing blame-avoidance posture involved congressional reaction to the CPSC's treatment of asbestos-containing hairdryers. In I977 the CPSC commissioned a report that found approximately roo consumer products, including hand-held hairdryers, to contain asbestos. The CPSC initially chose not to pursue the issue. When a television station had the hairdryers tested, one in five contained asbestos, some discharging asbestos fibers 'in the same range' as asbestos levels deemed hazardous in public schools (US Senate, I979: 3-4). These results, presented to the CPSC on 24 March I979, were broadcast on television four days later. Only then did Congress act: the chairman of the CPSC was called on the carpet in congressional hearings, providing representatives ample opportunity to excoriate the agency and to distance themselves from it politically (US House, I979: 78-84). A blame-avoidance mechanism was in place, and legislators used it.

Of course blame avoidance by Congress is by no means the only explanation of the CPSC experience. Much has been written about the effects of CPSC's status as a multi-member independent commission, the overall paucity of its regulatory activity, its reluctance to regulate chronic hazards, its choice of regulations with no significant effect on safety, and its adoption of regulations not warranted from a cost-benefit perspective (Viscusi, I984). On the congressional side, however, blame avoidance has been an important part of that story.

\subsubsection{Environmental Protection Agency (EPA)}

The EPA's asbestos air emissions and asbestos-in-schools regulations during this period exemplify ways in which blame-avoiding strategies were coupled with regulations that delivered less than they seemed to promise, making it difficult for the public to assess asbestos-related risks under the chosen regulatory structure. While the executive branch was 


\section{Charlotte Twight}

sometimes instrumental in bringing about these results, business interests, environmental groups, and the courts also played substantial roles in shaping EPA policy (Marcus, 1980; Wilson, 1989).

These regulations juxtapose conditions in which Congress in one case acquiesced in, and in another resisted, agency regulatory action. With air emissions, congressional acquiescence in transaction-cost-increasing measures accompanied a low-visibility regulatory policy: the chosen policy was complex and obscure enough to enable Congress to avoid blame and credibly convey the impression of appropriate action. With the school asbestos regulations, agency inaction due to executive branch pressure threatened Congress's ability to avoid blame in a highvisibility, publicity-generating policy arena: Congress accordingly fought the agency to protect its own blame-free posture. The school asbestos issue was more amenable than the air emission standard to oversimplification conducive to blame generation, and Congress in the school asbestos case went to greater lengths to avoid blame.

\section{Air Emissions}

During the I97os, the EPA's air emission standards for asbestos, like OSHA's regulations, were consistent with Congress's need to avoid blame, and Congress did not attempt to countermand those regulations. Having labeled asbestos a hazardous air pollutant in I97 I, the EPA in I973 issued regulations prohibiting 'visible emissions' from the milling and manufacturing of asbestos and prescribing asbestos-related work practices for building demolition, standards extended to building renovation and waste collection and disposal in 1975. In I973 the EPA restricted spray application of certain friable asbestos materials, tightening the regulations in I978. [36 Federal Register 593 I, 3 I March I97 I; 38 Federal Register 8829, 6 April I973; 40 Federal Register 8299, I 4 October I975; 43 Federal Register 26374, I9 June I978]. On the surface, these measures portrayed an activist government protecting citizens from asbestos-related harm.

They were useful first steps. However, unbeknownst to the average citizen, the 'no visible emissions' standard did not insulate the surrounding populace from asbestos-related disease. As experts inside and outside of government knew, asbestos fibers too small to be seen by the naked eye were highly toxic and long implicated in the etiology of asbestos-related disease. While the regulations offered some protection, they delivered much less than a nonspecialist would have inferred from their language, thereby shielding asbestos industry interests from political pressure for more costly cleanup efforts.

Regulations governing sprayed-on asbestos followed a similar pattern. 
Despite widespread belief that spraying of asbestos-containing materials (ACM) on interior surfaces of buildings was prohibited in 1973 , the only sprayings banned at that time were fireproofing and insulation applications - arguably uses with the greatest offsetting benefits. The EPA allowed applications labeled purely decorative to continue unabated until I 978.

From i973 until I978, with the risk to human health well known to policy specialists and others within government, thousands of tons of 'decorative' ACM were sprayed onto the ceilings and walls of homes and other buildings. Mere oversight? Perhaps, but one cannot overlook the government and industry interests that benefited from this little-understood policy. The government itself was releasing large quantities of asbestos from its own stockpile during this period, with major sales occurring in 1972 and 1974 (US House, I985a: $33^{8}$ ). Experts commissioned by the EPA later concluded that 'sprayed asbestos material within buildings may become the most significant source of environmental contamination in the future' (Sawyer \& Spooner, I978: I-I-6).

Additional transaction-cost augmentation buttressed these blameavoiding regulatory measures. For example, as late as 1982 the EPA continued in its public brochures to understate the scope of the asbestos problem, claiming that 'Some large buildings and a few homes built or remodeled between $\mathrm{I} 945$ and $\mathrm{I} 978$ may contain a crumbly, asbestoscontaining material which has been either sprayed or troweled onto the ceilings or walls' (US Environmental Protection Agency, i982: 6, emphasis added). More candid in their testimony before Congress, however, EPA officials allowed that 'any building' built from World War II through the i 960 s 'has as much chance [as schools] of having asbestos,' and that friable asbestos was estimated to be in 59 per cent of the large residential apartment buildings in a 1984 national survey population (US House, I986a: 34; US Senate, I988: 68).

\section{Asbestos in Schools}

The asbestos-in-schools issue during the early ig8os was promoted by Congress and resisted by the Reagan administration. After Congress passed the Asbestos School Hazard Detection and Control Act (ASHDCA) in I980 and the Asbestos School Hazard Abatement Act (ASHAA) in I984 [Public Law 96-27o, I4 June 1980, 94 Stat. 487; Public Law 98-377, I I August 1984, Title V, 98 Stat. I 287], the administration for ideological and budgetary reasons sought to block both funding and substantive regulations. Encountering this resistance, Congress used authorising legislation to avoid blame and ascribe it instead to the administration and the bureaucracy, simultaneously 


\section{74 Charlotte Twight}

claiming credit for congressional attempts to mitigate the school asbestos hazard (see US House, I982c, I983a).

ASHDCA appropriations were blocked while Carter was still president. The Act authorized the Department of Education to administer federal grants and interest-free loans to finance detection and cleanup of asbestos in schools. In r980 OMB rejected Education's appropriation request due to 'other budget priorities', and the programs were never funded (US General Accounting Office, I982: 2 I).

Executive resistance to the school asbestos programs and their funding continued for most of the two-term Reagan presidency (US House, I 984: 82; US House, I987a). The program's impairment was too great to allow Congress to retain its blame-free appearance, and Congress responded legislatively. For instance, when the administration pressured the EPA into abandoning its early efforts at a regulation specifying appropriate abatement actions, Congress passed new legislation mandating such regulations (see section 4.4. I, infra).

Blaming behavior continued throughout the period. For example, when in 1982 the EPA issued a rule governing identification of friable asbestos in elementary and secondary schools using authority under the Toxic Substances Control Act [47 Federal Register 2336o, 27 May I982; Public Law 94-469, i I October i 976, 9o Stat. 2003], Congress openly blamed the agency for the rule's deficiencies. ${ }^{10}$ In public hearings, representatives lashed out at EPA officials, asserting that the EPA was 'holding out the impression of action when there really isn't any action. ...' (US House, I986a: 22). As Rep. Norman Lent (R., N.Y.) stated, 'it is popular here in the Congress to heap all kinds of abuse on EPA and blame them for all the ills of the world during an election year' (US House, I984: I 2).

\subsubsection{Attempts to Limit Government Liability}

Any discussion of government blame avoidance during this period would be incomplete without reference to the US government's overt denials of asbestos-related liability and attempts to limit that liability via statutory law. Throughout the I970s and early i 980 , as asbestos litigation multiplied, government officials consistently disclaimed tort liability to asbestos victims. As J. Paul McGrath, Assistant Attorney General in the US Department of Justice, put it in 1982 , 'It is the basic position of the Government - and we have taken this in all the litigations - that the Government has no tort liability; that is, no liability in tort, to the victims of asbestos disease' (US House, I 982b: 5). Federal officials contended that the government's only potential liability was workers' compensation to federal employees under the Federal Employees' Com- 
pensation Act, arguing that the doctrine of sovereign immunity precluded asbestos tort claims.

As the I980s progressed, Congress investigated alternative settlement mechanisms, such as the private and voluntary Wellington group asbestos claims facility (US Senate, I985b). Concurrently, after its bankruptcy declaration in I982, the Manville Corporation (formerly Johns-Manville, the largest US asbestos firm) worked towards formation of a trust fund to compensate victims in lieu of judicial remedies. Fearing that the government might be the only remaining deep pocket if asbestos companies were destroyed by the extraordinary legal costs they were experiencing, Congress had strong incentives to facilitate these endeavors.

Meanwhile, members of Congress introduced numerous bills that would have curtailed asbestos victims' rights to pursue tort remedies against asbestos product manufacturers and the government. Although put forth as victim compensation bills, a critical provision in each was an 'exclusive remedy' clause that restricted the victim's compensation to amounts awarded under the bill's provisions. ${ }^{\text {II }}$ While parochial motives were sometimes transparent, some of these bills had a broad base of congressional support. ${ }^{12}$ Endorsing such measures gave the politically valuable appearance of support for victims' interests, while the exclusive-remedy provisions and limitations on governmental liability reduced the political cost of conveying that impression.

In the end, however, the changing informational context that gave increased political viability to victims' interest groups frustrated these maneuvers. Despite much testimony in numerous hearings, the bills were stymied by conflicting interest-group pressures, ${ }^{13}$ as members of Congress discovered that endorsement of such legislation would provoke blame. Interest groups were vocal on both sides of these bills, with victims' groups testifying to their 'unanimous outrage at this legislation' while industry representatives endorsed the measures (US Senate, I 985a: 31, 92, 1 26). In not passing the bills, Congress again took a blame-avoiding stance.

\subsection{Blame Avoidance, $1986-1989$}

Developments inside and outside of government contributed to changing public perceptions of asbestos health hazards in the early to mid-I98os. Inside government, activity surrounding the above-described legislative proposals increased public awareness of the issue. Jumping on the bandwagon [another blame-avoidance strategy identified by Weaver ( i 986)], the government itself disseminated information about asbestos health issues. A public information campaign sponsored by HEW in I978-1979 


\section{I $76 \quad$ Charlotte Twight}

accompanied an increase in the fraction of the American public aware of asbestos health risks from $5^{\circ}$ per cent to 68 per cent (US House, i $980 b$ : 34I). While HEW's action internally may be explained partly in terms of mission and executive politics, it also served the blame-avoidance motives then predominant in Congress. In 1978, a Congress member unquestionably would have made himself a target for blame by overtly opposing such information dissemination.

Outside government, the hearings and lawsuits prompted media coverage of the asbestos issue, which independently altered the constraints faced by politicians. When NOVA broadcast a moving documentary dealing with the issue in March I983, many Americans' perceptions of the asbestos issue were altered, and the cumulative impact of such media coverage redefined the political environment in which asbestos policy was made (US House, I983b: $286 \mathrm{ff}$.). The Manville Corporation bankruptcy settlement in I 986 provided further grist for the media mill. From a congressman's perspective in the midI 980 , support for the asbestos industry, if perceived by the public, threatened adverse electoral consequences.

By I986, circumstances thus were conducive to what I have labeled full-scale blame avoidance by federal policymakers. However, as noted in section 3.4, when Congress shifts from supporting the constituency formerly benefited by a policy (e.g., asbestos industry interests) to supporting the constituency previously harmed by that policy (e.g., asbestos victims), there is a mingling of blame-avoiding and credit-claiming motifs implicit in many policy actions. Measures adopted during this stage often may be characterized either as blame avoidance ('Don't blame me; I supported a statute mitigating harm to asbestos victims') or credit claiming ('Give me credit; I supported a statute mitigating harm to asbestos victims'). As discussed earlier, the theory does not rest on how we label this shift. Rather, the theory's central focus is the political environment for transaction-cost augmentation and its role in the timing of this change in constituent interests effectively driving the policy process.

Again, during this stage the appearance of not meriting blame rather than the reality of not taking blameworthy actions is the expected congressional desideratum. Theory here suggests political exaggeration of asbestos dangers coupled with dramatic steps to counteract the asserted crisis, accompanied by attribution of blame to others for past and present problems. In general, the greater public awareness and greater susceptibility of the issue to (blame-generating) oversimplification by rival politicians at this stage render likely more extreme congressional countermeasures. While this article does not attempt to specify optimal asbestos regulations, the incentives for transaction-cost augmentation in 
managing toxic substances thus invite regulation that is first late, then inadequate, and finally perhaps excessive.

In this context, the US government adopted two regulations most often cited as instances of overregulation: the 1987 asbestos-in-schools regulations and the 1989 EPA asbestos product ban. The school regulations have been criticized for imposing huge costs on schools while often worsening rather than mitigating asbestos-related risks (US Senate, I 988: 48, I84; Mossman et al., I990: 299; Abelson, I990). The asbestos product ban has been called economically inefficient on the grounds that it implies a cost per life saved far in excess of that for other lifesaving federal programs (Viscusi, I 989: 89, 99- Ioo; Morrall, I986). ${ }^{14}$

\subsection{1987 Asbestos-In-Schools Regulations}

Chiding the EPA for its prior inaction, Congress in I986 passed the Asbestos Hazards Emergency Response Act (AHERA), which required the EPA to develop regulations governing the appropriate response actions to deal with asbestos-containing materials in elementary and secondary schools (Public Law 99-519, 22 October I986, ioo Stat. 2970). Congress stressed the acute danger to school children, citing EPA estimates that 'I 5 million school children ... and I.4 million school employees attend school and work in buildings which have asbestos materials' (US House, ig86b: I4).

The EPA issued the required AHERA rules on 30 October 1987 ( 52 Federal Register 41826, 30 October 1987). Besides requiring local education agencies (LEAs) to have schools inspected by accredited inspectors and to develop a management plan for any ACM found, the new rules designated the circumstances in which five possible response actions could be undertaken by the LEAs. In addition, the regulations specified testing procedures to be used to ascertain completion of response actions, requiring the phasing in of transmission electron microscopy (TEM) testing over a two-year period.

Of most significance here, however, is the manner in which the EPA developed these regulations. Using what Congress and the EPA called 'regulatory negotiation' or negotiated rulemaking, the 'EPA established a committee of representatives of interested organizations, and charged them with the task of writing . . . a comprehensive regulatory proposal.' With Congress's tacit approval, the EPA delegated its responsibility to draft the AHERA regulations, openly committing itself 'to proposing whatever the committee can agree on' (US House, I987b: 66, I 26). That it did, and the committee's proposals were adopted.

Whatever its virtues in reducing bureaucratic costs and encouraging early compromise, the process provided an ideal vehicle for blame 


\section{78 Charlotte Twight}

avoidance at the congressional as well as agency levels. When complaints arise regarding the 1987 AHERA regulations, Congress - having passed the buck to the EPA - can use the EPA as its scapegoat, and the EPA in turn can blame the actual interest-group decisionmakers to whom it passed the buck. As predicted by the theory, Congress with its AHERA policies positioned itself to gain high-profile credit for preventing asbestos-related harm to school children while establishing a protective institutional web to facilitate blame avoidance.

\subsubsection{I989 Asbestos Product Ban}

Through the I976 Toxic Substances Control Act, Congress delegated broad powers to the EPA to regulate toxic substances when piecemeal regulation by other agencies was deemed insufficient to protect public health. In i 984 , the EPA attempted to use these powers to phase down and ban the use of certain asbestos products. However, its initial attempts were thwarted by opposition from industry interests and the Office of Management and Budget (OMB) (Twight, I99I). Executive pressure drove the outcome, as OMB used its regulatory review authority ${ }^{15}$ under Executive Order I 229 I to 'surreptitiously relay the position of interested parties' in a way that the House subcommittee on oversight and investigations deemed 'an unlawful abuse of power' (US House, I985b: 387 ; i $985 \mathrm{c}: 7$ ).

Criticized by some members of Congress for this capitulation to OMB and industry pressure (US House, I985b, I985c), the EPA renewed its resolve to press forward with the regulations. The EPA reformulated its proposal so as to accommodate OMB's criticisms, gained OMB's approval, and announced its proposed rulemaking on 29 January i 986.

Despite this approval, however, OMB's resistance continued. It met off the record with Canadian officials to assuage their concerns regarding Canada's asbestos interests, describing OMB's strategies for continued opposition to the EPA rule. OMB official Robert Bedell coached the Canadians on ways to oppose the EPA's proposal and invited them to submit additional information directly to OMB. Rep. Ron Wyden (Ore.) characterized OMB's actions as 'conspiring with officials of a foreign government to sabotage the proposed rule' (US House, ig86c: I36).

Not until 1989 - five years after its initial efforts and thirteen years after enactment of the TSCA - did the EPA adopt regulations phasing down and banning use of asbestos products. The I989 regulations instituted a prospective ban on the manufacture, processing, importation, and distribution of asbestos products such as asbestos clothing, floor tile, felt, cement sheet, friction products (including brake linings 
and pads), paper, cement pipe, and shingles (54 Federal Register 2946o, I 2 July I989). Designed to be phased in over an eight year period, the ban will be fully effective in 1997 .

This case is remarkable for several reasons. First, we again encounter Congress's blame-avoiding predilection to delegate responsibility. Second, we see strong evidence of asbestos industry influence on federal decisionmakers, reflected in executive branch pressure on the EPA pressure strong enough to block even the proposal for rulemaking until I 986 . Third, the increase in congressional pressure on the EPA to resist the OMB and industry interests occurred beginning in 1985 , about the time when the exogenous political constraint of public awareness became conducive to full-scale blame avoidance. At the expected time, Congress positioned itself politically to claim credit for dealing with asbestos hazards now more fully understood by the public, simultaneously insulating itself from blame for any political missteps by the EPA.

While some wonder why it took until 1989 to initiate a ban on products known to be hazardous for decades, others view this as an instance of overregulation (Morrall, I986; Viscusi, I989: 99-10o). From the theoretical perspective of this paper, neither occurrence is unexpected. Observed policymaking in this instance - whether or not these particular regulations are judged economically inefficient - is fully consistent with the predicted responsiveness of congressional policy to changing political constraints on transaction-cost augmentation.

\section{Implications for Future Research}

This paper has described the choice between credit claiming and blame avoidance as a function of officeholders' ability to practice transactioncost augmentation. Transaction costs facing the public on political issues have been shown to be malleable within bounds whose scope from the government's perspective - is determined both endogenously and exogenously. We have seen that the model yields distinctive predictions about the timing of public policy changes and about the types of transaction-cost augmentation likely to accompany open credit claiming, concealed credit claiming, early-stage blame avoidance, and fullscale blame avoidance.

Whereas other models imply that a change from credit claiming to blame avoidance will occur when officeholders recognize that a policy imposes high per capita costs on a sizeable portion of their constituency, this model predicts that the change is most likely to occur when exogenously determined constraints on transaction-cost augmentation make it impossible for officeholders to blunt the negative electoral conse- 
quences of the harm-generating policy. This model further predicts that, until such a political environment materializes, officeholders will use transaction-cost augmentation to sustain credit-claiming strategies on behalf of the policy's beneficiaries.

In the future, the model's predictions can be assessed against the evolution of policies pertaining to issues other than the asbestos case examined here. For example, further research might investigate the evolution of the US government's hazardous waste policies, the Gramm-Rudman-Hollings deficit reduction law and its implementation, Forest Service policies, nuclear power policies, savings and loan industry policies, and other policy issues for consistency with the predictions of this model.

Future research might also explore the degree to which the US experience is exceptional. Political striving for power, autonomy, and esteem is not confined to the US. While constraints will differ internationally, political manifestations of credit claiming and blame avoidance involving transaction-cost augmentation can be expected to be apparent in cultures and institutional contexts outside the US.

Of course, differences in political institutions strongly affect politicians' ability to control information flows and other types of transaction costs, and hence their ability to claim credit or avoid blame. Consequently, this model offers extensive opportunities for cross-cultural comparison and prediction with respect to specific governmental policies. If, as this model suggests, policy-specific transaction costs facing citizens are politically malleable, one can make predictions concerning how the incentive and ability to practice transaction-cost augmentation in specific policy contexts will differ in different countries.

Institutional inducements for this behavior will vary depending on a nation's political structure (e.g., authoritarian or democratic regime), economic status (e.g., Third World or industrialized nation), and other variables. Based on the institutional structure of government and upon the nation's level of economic development, this model would generate different predictions concerning the evolution of asbestos (or some other) policy in India or China than in the United States. The incentive for government officials to practice transaction-cost augmentation regarding an issue like asbestos is undoubtedly greater the poorer the nation, while their ability to practice transaction-cost augmentation is greater the more extensive the government's political power and the less educated the citizenry. ${ }^{16}$ Consistent with these expectations, Dahl ( 1989 ) reported that Canada currently 'is exporting close to half its asbestos to the Third World, where many workers are still oblivious to its dangers.'

The incentive to practice transaction-cost augmentation also depends on the economic importance of relevant interest groups in a country. As 
we have seen, Canada, one of the world's largest asbestos producers, not only has attempted to manipulate US asbestos policy but also has conducted major promotional efforts in Third World countries that lack both knowledge about asbestos and a regulatory framework for dealing with it (Sentes, I989). Canada has made major inroads in Thailand, where 'Construction workers, who didn't even know what asbestos was, were enveloped in clouds of dust as they used power saws to cut asbestos cement pipes and sheeting,' and 'Outside the plant the workers' children were roaming the company compound among discarded equipment, empty asbestos bags, and mounds of waste asbestos' (Sentes, 1989: 7). That the balance of producer, user, and consumer interests affects outcomes also seems consistent with the Swedish experience (Kelman, I98 I: 77-80). More detailed evaluation of these and related issues in an international context awaits further research.

If this model accurately portrays a characteristic aspect of political decisionmaking, one may reflect on its policy implications. Given a policy issue such as asbestos with substantial but difficult to detect adverse effects on a particular constituency segment, and given policymakers' predilection for transaction-cost augmentation, which of the four policy stances discussed in Section 3 is most likely to facilitate decisionmaking in accord with the views of an informed citizenry? Perhaps none.

In the presence of transaction-cost augmentation, open or concealed credit claiming is clearly incompatible with citizens' ability to make informed risk-benefit tradeoffs. These policy stances tend to stifle the information dissemination that would facilitate individual choice based on risk aversion and opportunity costs. Preliminary blame avoidance has the virtue of impelling actions that spread risk information to the general public and discouraging further credit-claiming actions on behalf of industry interests that would exacerbate the harm. However, this policy mien characteristically spawns measures that promise more than they deliver, imparting false perceptions of security. Full-scale blame avoidance, by comparison, involves added potential to inspire unjustifiably burdensome regulation.

Officeholders will continue to augment transaction costs subject to prevailing constraints. Citizens will continue to receive information distorted by politicians' efforts to shape it to their own ends. Policymaking will be improved to the extent that institutional structure facilitates competition in these information-generation functions, thereby more rapidly and more severely constraining self-serving political attempts to keep public knowledge in check. 


\section{NOTES}

I. By focusing chiefly on US congressional behavior, this article does not denigrate the importance of the federal bureaucracy and executive branch in shaping asbestos policy nor imply that Congress dominates day-to-day agency decisionmaking. Congress's authorization and appropriation decisions establish constraints on agency behavior, but within those bounds agency decisions are driven by a complex admixture of agency mission, executive branch pressure, congressional pressure, and other political and institutional variables (Wilson, i 989). In the US, many pressures besides those from Congress have shaped the resultant asbestos rules, most prominent among them pressure from the executive branch. That is consistent with the transaction-cost augmentation model (discussed in section 3 ), which predicts that executive pressure will more strongly influence agency decisionmaking than congressional decisionmaking on these issues. But in a larger sense many agency rules, in the long run, may come to reflect congressional policy - or at least acquiescence - given the existing constellation of pressures on Congress. This is not true if the principal-agent problem is so severe that none of Congress's policy-control mechanisms (budget, legislation, appointments) work (Moe, 1987), or if agencies successfully practice long-term deception of Congress so that control mechanisms that would be triggered with correct information are never applied. But in other situations, Congress in the long run can (and sometimes does) exercise its authorization and appropriation powers to attempt to redirect agency policies not in accord with the views of a majority in the legislature. If it does not do so, then - viewed through the lens of constrained congressional power to alter the mission, authority, and resources of the agencies - it becomes more plausible over time to view agency regulatory activity as a manifestation of congressional will.

2. Transaction costs denote costs of reaching and enforcing agreements, costs that exist due to the multi-party character of (political or economic) exchange. Transaction costs thus include information costs as well as other costs of negotiating and policing consensual decisions, whether in political or economic contexts. See note 3 for examples of transaction-cost augmentation.

3. Previously cited examples of information-cost augmentation include: 'semantic efforts to alter public perception of the costs or benefits of government activities; forms of taxation that change people's perception of the actual tax burden imposed upon them; forms of subsidy that alter public perception of the benefit implied; forms of regulation that obscure its cost to the individual; choice of nonmarket (coercive) government procurement instead of purchase in the open market; the choice between taxation, subsidy, and regulation as means of benefiting producer groups; overt distortion of information about the nature and consequences of government activities; restriction of access to information about the nature of government activities; prohibition of legitimate private contracts so as to increase the information costs of evaluating private alternatives to government control; and 'off-budget' techniques that increase private citizens' costs of assessing the full cost of certain government activities.' Other examples of governmental transaction-cost augmentation include: 'changing the locus of decision-making authority in ways that shift the transaction-cost burden entailed in effectuating or forestalling change in the role of government; unilaterally reinterpreting and implementing prevailing statutory and administrative rules to imbue the government with a changed scope of decisionmaking authority; changing the cost to private citizens of achieving political agreement to revise the scope of governmental authority; interaction between governmental agencies that alters the cost to individuals of revising the scope of government authority; fostering creation of institutional agents with incentives structured to encourage their promotion of federal policy in diverse areas; manipulating noninstitutional private agents through incentives structured to encourage their promotion of federal policy in diverse areas; concentrating the benefits and dispersing the harm born of government action; changing the cost to private individuals of effecting administrative or judicial challenge to the government's interpretation of its existing powers; and enacting federal rules that alter costs to agencies, courts, or other governmental bodies (or their functionaries) associated with interpreting and implementing their decisionmaking authority.' Twight, I988: I 50, notes 1 and 2.

4. Natural transaction costs are the transaction costs that remain when everyone attempts to minimize the wealth-reducing impact of transaction costs. Natural transaction costs exclude those transaction costs deliberately created by one person to reduce the wealth of another. Natural transaction costs thus represent an unavoidable constraint, given existing technological and organizational means of reducing transaction costs. See Twight, I 988 : I 5 I, n. 9 .

5. These include agenda limitation, redefining the issue, throwing good money after bad, passing 


\section{From Claiming Credit to Avoiding Blame}

the buck, finding a scapegoat, jumping on the bandwagon, diffusing blame by spreading it among many policymakers, and limiting discretion over choices representing credit-claiming opportunities in conflict with officeholders' policy preferences (Weaver, 1986: 384-39o). Regarding delegation of responsibility to administrative agencies as a blame-avoiding strategy, see Wilson (1989: 246, note).

6. While I classify asbestos policy during this period as concealed credit claiming, its blame avoiding features are apparent. By impeding the general public's acquisition of knowledge about the harm these policies caused, officeholders temporarily deflected blame for their initiation and continuation of these policies. However, it is useful to distinguish this type of cost concealment, feasible only in a situation characterized by relatively high natural transaction costs, from the blame-avoidance strategies employed (as with asbestos policy after 1970) when natural transaction costs facing the public on a policy question are relatively low.

7. Although the danger to those who worked with the raw fibers was well known in the I93os, controversy remained concerning the risk to workers who handled asbestos insulation. While scientific literature suggested the hazard much earlier, the New York Academy of Sciences' international conference on the biological effects of asbestos held in 1964 irrefutably established the magnitude of the threat to insulators.

8. The congressional dominance model, developed by Weingast and Moran (1983), Fiorina ( 198 I ), McCubbins and Schwartz ( 1984$)$, and others, has been challenged by Moe (1987). See Wilson ( I989: 254-256) and note I, supra.

9. 36 Federal Register 10466, 29 May 197 ; 36 Federal Register 23207, 7 December 197 ; 37 Federal Register I I 318, 7 June 1972; 5I Federal Register 226 1 2, 20 June 1986. Acting under court order [Building $\mathcal{E}$ Construction Trades Department v. Brock, $8{ }_{3} 8$ F.2d 1258 (D.C. Cir., I988)], OSHA recently proposed to reduce the permissible exposure limit to o. I f/cc (55 Federal Register 297 I 2, 20 July i 990 ).

Io. The rule required inspections and mandated notification of parents and school personnel of any friable asbestos-containing materials found. However, inspections did not have to be made by qualified personnel, and no abatement actions were required. Compliance was achieved in only about a third of the affected schools (Christensen \& Larscheid, I988: 462).

II. See, for example, H.R. I626, the 'Asbestos Workers' Recovery Act,' and H.R. 309o, the 'Occupational Disease Compensation Act of 1985 ,' both 99th Cong., Ist Sess.; as well as the 'Occupational Health Hazards Compensation Act of 1 982,' 97 th Cong., 2d Sess. For discussion of these bills, see US House, I985a and US House, I982a. Leaders of victims' interest groups were not deceived. Opposing such bills in $198_{5}$, Paul Safchuck, President of the White Lung Association, asked members of Congress 'If you are really so sure that this is such a good system for compensating us, why don't you let us decide if we want to use it? ... [I]f you take away our rights to use the courts around this question, you have taken away one of our basic rights as American citizens' (US House, I985a: 247).

I 2. A 1977 bill entitled the 'Asbestos Health Hazards Compensation Act' - introduced by Rep. Millicent Fenwick, whose district was home to the Johns Manville Corporation - epitomized parochial use of the asbestos compensation issue. (Asbestos Health Hazards Compensation Act, H.R. 8689, 2 August I 977, 95th Cong., ist Sess). These were not, however, single-sponsor measures. For example, the Asbestos Workers Recovery Act was sponsored by 5 senators and 65 representatives (U.S. Senate, I985a: 79).

13. Robert Willmore of the US Department of Justice noted the interest-group politics impeding the bills: ' $[\mathrm{P}]$ art of the difficulty of any legislative effort is that there are too many interest groups seeking something out of the legislation other than solving the asbestos litigation crisis. ... As long as those forces are as effective as they seem to be today, any effort at enacting legislation is going to be futile' (US House, I985a: 306-307).

14. These studies concluded that the EPA's asbestos product ban, as proposed in I986, involved costs per life saved of $\$_{104}, 200,000-$ far in excess of estimates of private valuation of life and greatly in excess of costs per life saved in many other regulatory programs (Morrall, I986: 30, 34). However, since the Office of Management and Budget (OMB) generated the underlying data, OMB's political agenda regarding asbestos also is relevant to impartial assessment of these estimates. See section $4 \cdot 4 \cdot 2$, infra.

I 5. OMB authority to review proposed agency regulations stems from Executive Order I 229 I, 46 Federal Register 1 3193, I9 February 198 I, and Executive Order I 2498, 50 Federal Register 1036, 8 January I 985 . According to Rep. James Florio (N.J.), one reason OMB resisted the EPA bans was fear that such regulatory action would increase pressure on the government to 'assume 


\section{I84 Charlotte Twight}

some financial responsibility' for claims in asbestos lawsuits brought by shipyard workers (US House, 1984: 2).

16. The extraordinary pollution levels in Eastern Europe and the Soviet Union seem consistent with these suppositions. Also seemingly consistent is the fact that, when home-country asbestos regulations were tightened, British firms moved overseas to India, where they maintained piles of asbestos waste open to children who played on it (US House, r983b: 301 ).

\section{REFERENCES}

Abelson, Philip H. ( I 990) 'The Asbestos Removal Fiasco,' Science, 247 (2 Mar.) Ior 7.

$\rightarrow$ Austen-Smith, David and William H. Riker ( 1987 ) 'Asymmetric Information and the Coherence of Legislation.' American Political Science Review, 8I (3) 897-9r 8.

Austen-Smith, David and William H. Riker (I990) 'Asymmetric Information and the Coherence of Legislation: A Correction.' American Political Science Review, 84 ( I) 243-245.

$\rightarrow$ Bendor, Jonathan, Serge Taylor and Roland Van Gaalen ( 1987 ) 'Politicians, Bureaucrats, and Asymmetric Information.' American Journal of Political Science, 31 (4) 796-828.

Bosso, Christopher J. (1987) Pesticides and Politics: The Life Cycle of a Public Issue. Pittsburgh, Pa.: University of Pittsburgh Press.

Buchanan, James M. (1967) Public Finance in Democratic Process. Chapel Hill, N.C.: University of North Carolina Press.

Castleman, Barry ( 1986 ) Asbestos: Medical and Legal Aspects, 2d ed. Clifton, New Jersey: Prentice Hall Law \& Business.

Christensen, Barbara M. and Kristine A. Larscheid (r988) 'Asbestos Abatement: The Second Wave of the Asbestos Litigation Industry.' Washburn Law Journal, 27 (3) 454-494.

Crew, Michael and Twight, Charlotte (r99o) 'On the Efficiency of Law: A Public Choice Perspective.' Public Choice, 66 ( I) I 5-36.

Dahl, Jonathan ( I989) 'Canada Encourages Mining of Asbestos, Sells to Third World.' Wall Street Journal (I 2 Sept.) AI, AI 2.

Dreessen, W. C., J. M. Dallavalle, T. I. Edwards, J. W. Miller and R. R. Sayers ( 1938 ) 'A Study of Asbestosis in the Asbestos Textile Industry.' Public Health Bulletin No. 24I: US Treasury.

Fiorina, Morris P. (1977) Congress: Keystone of the Washington Establishment. New Haven: Yale University Press.

Fiorina, Morris P. (r98I) 'Congressional Control of the Bureaucracy: A Mismatch of Incentives and Capabilities.' In Lawrence C. Dodd and Bruce I. Oppenheimer (eds.), Congress Reconsidered, 2d ed. Wash., D.C.: Congressional Quarterly Press.

Higgs, Robert (1987) Crisis and Leviathan: Critical Episodes in the Growth of American Government. New York: Oxford University Press.

Hoffman, Frederick L. (1918) 'Mortality from Respiratory Diseases in Dusty Trades.' Bulletin No. 23I, Bureau of Labor Standards, US Bureau of Labor.

Kelman, Steven (i980) 'Occupational Safety and Health Administration.' In James Q. Wilson (ed.), The Politics of Regulation. New York: Basic Books, Inc.

Kelman, Steven ( 198 I ) Regulating America, Regulating Sweden: A Comparative Study of Occupational Safety and Health Policy. Cambridge, Mass.: The MIT Press.

Kelman, Steven (1987) Making Public Policy: A Hopeful View of American Government. New York: Basic Books, Inc.

Lanza, Anthony J. (1935) 'Effects of the Inhalation of Asbestos Dust on the Lungs of Asbestos Workers.' Public Health Report, Vol. 50: US Treasury.

Lindsay, C. M. (1976) 'Pork-Barrel Politics and the 'Fog' Factor'. Unpublished manuscript: University of California at Los Angeles; Arizona State University.

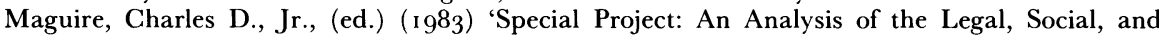
Political Issues Raised by Asbestos Litigation.' Vanderbilt Law Review, 36 (3) 573-846.

Marcus, Alfred ( 1980) 'Environmental Protection Agency.' In James Q. Wilson (ed.), The Politics of Regulation. New York: Basic Books, Inc.

Mayhew, David (1974) Congress: The Electoral Connection. New Haven: Yale University Press.

$\rightarrow$ McCubbins, Mathew and Thomas Schwartz ( 1984) 'Congressional Oversight Overlooked: Police Patrols Versus Fire Alarms.' American Journal of Political Science, 28, i65-1 79.

Moe, Terry M. (1987) 'An Assessment of the Positive Theory of "Congressional Dominance.", Legislative Studies Quarterly, XII (4) 475-520. 


\section{From Claiming Credit to Avoiding Blame}

Morrall III, John F. (I 986) 'A Review of the Record.' Regulation (Nov.-Dec.) 25-34.

Mossman, B. T., J. Bignon, M. Corn, A. Seaton and J. B. L. Gee (1990) 'Asbestos: Scientific Developments and Implications for Public Policy.' Science, 247 (19 Jan.) 294-30 I.

Nordlinger, Eric A. (1981) On the Autonomy of the Democratic State. Cambridge, Mass.: Harvard University Press.

Peltzman, Sam (1976) 'Towards a More General Theory of Regulation.' Journal of Law and Economics I9 (2) 2 I I-240.

Rose, Richard (1977) 'The President: A Chief But Not an Executive.' Presidential Studies Quarterly 7 (1) 5-20.

Sawyer, Robert N. and Charles M. Spooner (1978) Sprayed Asbestos-Containing Materials in Buildings: A Guidance Document. EPA contract, EPA-450/2-78-014, OAQPS No. I.2-094. Research Triangle Park, N.C. (March).

Selikoff, I. J., E. C. Hammond and J. Churg (1965) 'The Occurrence of Asbestosis Among Insulation Workers in the United States.' Annals of the New York Academy of Sciences, 132, I 39- 155.

Sentes, Ray (1989) 'The Asbestos Albatross.' Policy Options Politiques, (Dec.) 3-8.

Shapiro, Sidney A. and Thomas O. McGarity (1989) 'Reorienting OSHA: Regulatory Alternatives and Legislative Reform.' Yale Journal on Regulation, 6 ( I) I-63.

Twight, C. A. L. ( 1983 ) Government Manipulation of Constitutional-Level Transaction Costs: An Economic Theory and Its Application to Off-Budget Expenditure Through the Federal Financing Bank. Seattle, Wash.: University of Washington.

Twight, Charlotte (1988) 'Government Manipulation of Constitutional-Level Transaction Costs: A General Theory of Transaction-Cost Augmentation and the Growth of Government.' Public Choice, 56 (2) $133^{1-1} 5^{2}$.

Twight, Charlotte (I99I) 'Regulation of Asbestos: The Microanalytics of Government Failure.' Policy Studies Review, forthcoming.

U.S. Bureau of Mines, US Department of the Interior. Minerals Yearbook, various years.

U.S. Environmental Protection Agency (1982) Asbestos in the Home. Wash., D.C.: Government Printing Office.

U.S. General Accounting Office (1982) Asbestos in Schools: A Dilemma. GAO Report B-206367, GAO/CED-82-1 I 4. Gaithersburg, Md.: US General Accounting Office.

U.S. House of Representatives ( I92 I ) Comm. on Ways and Means. General Tariff Revision, Part 5 . Hearing, 66th Cong., 3d Sess.

U.S. House of Representatives (1929) Comm. on Ways and Means. Tariff Readjustment. Hearing, 7oth Cong., 2d Sess.

U.S. House of Representatives (1956) Comm. on Interior and Insular Affairs. Providing for the Maintenance of Production of Tungsten, Asbestos, Fluorspar, and Columbium-Tantalum in the United States, Its Territories, and Possessions. Report No. 2596, 84th Cong., 2d Sess.

U.S. House of Representatives (1978) Comm, on Education and Labor, Subcomm. on Compensation, Health and Safety. Asbestos-Related Occupational Diseases. Hearing, 95th Cong., 2d Sess.

U.S. House of Representatives (1979) Comm. on Interstate and Foreign Commerce, Subcomm. on Consumer Protection and Finance. Hair Dryers Containing Asbestos. Hearing, 96th Cong., Ist Sess.

U.S. House of Representatives ( $1980 a$ ) Comm. on Education and Labor, Subcomm. on Health and Safety. Oversight Hearings on OSHA - Occupational Safety and Health for Federal Employees, Part 3: Federal Sector. Hearing, 96th Cong., 2d Sess.

U.S. House of Representatives ( $1980 \mathrm{ob}$ ) Comm. on Merchant Marine and Fisheries, Subcomm. on Coast Guard and Navigation, and Subcomm. on Fisheries and Wildlife Conservation and the Environment. IXTOC I Pollution Compensation - Shipboard Asbestos Exposure - Marpol Protocol. Hearing, 96th Cong., ist and 2d Sess.

U.S. House of Representatives (198I) Comm. on Education and Labor. The Attorney General's Asbestos Liability Report to the Congress. Comm. Print, 97th Cong., ist Sess.

U.S. House of Representatives (I982a) Comm. on Education and Labor, Subcomm. on Labor Standards. Occupational Health Hazards Comepnsation Act of 1982 . Hearing, 97th Cong., 2d Sess.

U.S. House of Representatives (1982b) Comm. on Education and Labor, Subcomm. on Labor Standards. Oversight Hearing on the Effect of the Manville and UNR Bankruptcies on Compensation of Asbestos Victims. Hearing, 97th Cong., 2d Sess.

U.S. House of Representatives ( $1982 \mathrm{c}$ ) Comm. on Energy and Commerce, Subcomm. on Commerce, Transportation, and Tourism. EPA's Failure to Regulate Asbestos Exposure. Hearing, 97th Cong. $2 \mathrm{~d}$ Sess.

U.S. House of Representatives (1983a) Comm. on Education and Labor, Subcomm. on Elemen- 
This document was originally published by Cambridge University Press in Management. Journal of Public Policy. Copyright restrictions may apply. DOI: 10.1017/S0143814X00006188

\section{86 Charlotte Twight}

tary, Secondary, and Vocational Education. Oversight Hearing on Asbestos Hazards in Elementary and Secondary Schools. Hearing, 98th Cong., ist Sess.

U.S. House of Representatives ( $1983 \mathrm{~b}$ ) Comm. on Government Operations, Subcomm. on Manpower and Housing. Failure to Regulate-Asbestos: A Lethal Legacy. Hearing, 98th Cong., ist Sess.

U.S. House of Representatives ( 1984 ) Comm. on Energy and Commerce, Subcomm. on Commerce, Transportation, and Tourism. Federal Efforts to Control Asbestos Hazards. Hearing, 98th Cong., 2d Sess.

U.S. House of Representatives (1985a) Comm. on Education and Labor, Subcomm. on Labor Standards. Hearing on Compensation for Occupational Diseases. Hearing, 99th Cong., ist Sess.

U.S. House of Representatives ( 1985 b) Comm. on Energy and Commerce, Subcomm. on Oversight and Investigations. EPA's Asbestos Regulations. Hearing, 99th Cong., ist Sess.

U.S. House of Representatives ( $1985 \mathrm{c}$ ) Comm. on Energy and Commerce, Subcomm. on Oversight and Investigations. EPA's Asbestos Regulations: Report on a 'Case Study on OMB Interference in Agency Rulemaking.' Comm. Print 99-V, 99th Cong., ist Sess.

U.S. House of Representatives (1986a) Comm. on Energy and Commerce, Subcomm. on Commerce, Transportation, and Tourism. Asbestos Exposure. Hearing, 99th Cong., ist and $2 \mathrm{~d}$ Sess.

U.S. House of Representatives ( $1986 \mathrm{~b}$ ) Comm. on Energy and Commerce. House Report No. 99--763 [To Accompany H.R. 5073]. 99th Cong., 2d Sess.

U.S. House of Representatives (1986c) Comm. on Energy and Commerce, Subcomm. on Oversight and Investigations. $O M B$ Review of EPA Regulations. Hearing, 99th Cong., 2d Sess.

U.S. House of Representatives ( 1987 a) Comm. on Energy and Commerce, Subcomm. on Transportation, Tourism, and Hazardous Materials. Asbestos in Schools. Hearing, Iooth Cong., ist Sess.

U.S. House of Representatives (1987b) Comm. on Government Operations, Subcomm. on Environment, Energy, and Natural Resources. Asbestos Dangers: Presence in Schools and Incompetent Disposal. Hearing, Iooth Cong., ist Sess.

U.S. Senate ( 1936 ) Comm. on Education and Labor, Subcomm. on S. Con. Res. 34. Silicosis and Metal-Mining Conditions. Hearing, 74th Cong., 2d Sess.

U.S. Senate (1979) Comm. on Commerce, Science, and Transportation; Subcomm. for Consumers. Asbestos in Hand-Held Hair Dryers. Hearing, 96th Cong., ist Sess.

U.S. Senate (1985a) Comm. on Finance, Subcomm. on Health. Asbestos Workers' Recovery Act. Hearing, 99th Cong., ist Sess.

U.S. Senate (1985b) Comm. on Labor and Human Resources, Subcomm. on Labor. Proposed Asbestos Claims Facility. Hearing, 99th Cong., ist Sess.

U.S. Senate (1988) Comm. on Environment and Public Works, Subcomm. on Hazardous Wastes and Toxic Substances, and Subcomm. on Superfund and Environmental Oversight. Implementation of the Asbestos Hazard Emergency Response Act. Joint Hearing, rooth Cong., 2d Sess.

Viscusi, W. Kip ( $\left.\mathrm{I}^{8}{ }_{3}\right)$ Risk by Choice: Regulating Health and Safety in the Workplace. Cambridge, Mass.: Harvard University Press.

Viscusi, W. Kip (1984) Regulating Consumer Product Safety. Wash., D.C.: American Enterprise Institute for Public Policy Research.

Viscusi, W. Kip ( I 989) 'Toward a Diminished Role for Tort Liability: Social Insurance, Government Regulation, and Contemporary Risks to Health and Safety.' Yale Journal on Regulation, 6 (I) 65-107.

$\rightarrow$ Weaver, R. Kent (I 986) 'The Politics of Blame Avoidance.' Journal of Public Policy, 6 (4) 37 I-398.

Weaver, R. Kent ( 1988$)$ Automatic Government: The Politics of Indexation. Wash., D.C.: The Brookings Institution.

$\rightarrow$ Weingast, Barry R. and Mark J. Moran (1983) 'Bureaucracy Discretion or Congressional Control? Regulatory Policymaking by the Federal Trade Commission.' Journal of Political Economy, 91, 765-8oo.

West, E. G. and Stanley L. Winer (r980) 'Optimal Fiscal Illusion and the Size of Government.' Public Choice, 35 (5) 607-622.

Wilson, James Q. (1989) Bureaucracy: What Government Agencies Do and Why They Do It. New York: Basic Books, Inc. 